<단보>

배합사료의 소맥분 함량이 곳체다슬기, Semisulcospira
gottschei 의 성장 및 체조성에 미치는 영향

김경덕**김대희 $\cdot$ 김강웅·손맹현·강용진 ${ }^{1} \cdot$ 백재민 $^{1} \cdot$ 이상민 ${ }^{2}$

국립수산과학원 사료연구센터, ${ }^{1}$ 중앙내수면연구소, ${ }^{2}$ 강릉원주대학교 해양생명공학부

\title{
Effects of Dietary Wheat Flour Content on the Growth and Body Composition of the Snail, Semisulcospira gottschei
}

\author{
Kyoung-Duck Kim*, Dae-Hee Kim, Kang-Woong Kim, Maeng Hyun Son, \\ Yong Jin Kang ${ }^{1}$, Jae Min Baek ${ }^{1}$ and Sang-Min Lee ${ }^{2}$ \\ Aquafeed Research Center, National Fisheries Research \& \\ Development Institute, Pohang 791-923, Korea \\ ${ }^{1}$ Inland Fisheries Research Institute, National Fisheries Research \& \\ Development Institute, Gapyeong 477-815, Korea \\ ${ }^{2}$ Faculty of Marine Bioscience \& Technology, Gangneung-Wonju \\ National University, Gangneung 210-702, Korea
}

This study investigated the effect of wheat flour content in the diet on the growth of the snail Semisulcospira gottschei. Six diets were prepared containing wheat flour contents of $35,40,45,50,55$, and $60 \%$. Three replicate groups of snails (average weight $0.61 \mathrm{~g}$ ) were fed each experimental diet for 8 weeks. The survival was above $85 \%$ in all groups, and did not differ significantly among treatments. The weight gain of snails fed the diets containing 35 and $40 \%$ wheat flour was significantly higher than that of snails fed the other diets $(P<0.05)$, and the weight gain decreased when the dietary wheat flour content increased beyond $45 \%$. The crude protein and ash contents in snails were significantly affected by the dietary wheat flour content $(P<0.05)$. Therefore, a diet containing 35 40\% wheat flour produces the optimal growth of snails. The results of this study will be used to develop cost-effective diets for commercial snail production.

Key words: Semisulcospira gottschei, Wheat flour, Diet, Growth

\section{서 론}

곳체다슬기는 우리나라, 일본, 타이완 및 중국의 하천에 널리 서식하며 (Davis, 1969), 특히 다슬기는 삶아서 가식부를 그대로 식용하거나, 탕 및 액기스와 같은 건강식품으로 소비 자의 수요가 증가함에 따라 담수 양식종으로 가치가 높은 종이다. 다슬기의 연간 국내 생산량은 2009년에 930톤이며 (어업생산통계), 수입량 (패각 제외 가식부)은 1434톤에 달하 고 있다 (국립수산물품질검사원). 이와 같이 다슬기의 국내 어획량은 수요량에 비하여 제한적인 실정이어서 다슬기 양식 을 시도하는 양어가들이 증가하는 추세에 있다. 다슬기 양식 장에서 어미로부터 출산된 다슬기 종묘는 파판에 부착된 식물 성 플랑크톤을 섭취하며 $5 \mathrm{~mm}$ 전후의 크기까지 성장한 이후 에는 다슬기 사육에 적합한 배합사료가 개발되어 있지 않아 타 어종의 배합사료를 사용하거나 냉동어육 등을 공급하는 실정이다. 이와 같은 타 어종용 사료의 사용은 각종 영양소 함량의 과다 혹은 부족으로 다슬기의 사료효율 저하 및 성장 을 감소시킬 수 있어 양식생산 비용을 증가시키는 문제점을 발생시킬 수 있다. 이러한 문제점 해결을 위해서는 다슬기 사육에 적합한 실용배합사료를 개발하여 양식생산성을 높이 는 반면, 경제적인 사료원료의 이용성을 조사하여 사료 가격

\footnotetext{
*Corresponding author: kdkim@nfrdi.go.kr
}

을 지속적으로 낮추는 것이 필요하다.

곳체다슬기는 어류와 달리 움직임이 느리고 먹이를 서서히 조금씩 갉아먹는 습성이 있으므로, 먹이를 섭취하는데 충분한 시간이 필요하며 먹이 섭취 전까지 사료의 영양소가 수중으로 유출되는 것을 최소화하여야 한다. 곳체다슬기용 사육에 적합 한 사료 개발을 위하여 사료형태를 달리하여 사육 실험한 결과, 플레이크 형태의 사료 공급은 분말 및 펠렛 사료에 비하 여 오히려 다슬기의 사료 섭취를 어렵게 하여 성장을 감소시 키는 것으로 보고되었다 (Hwang et al., 2003). 그리고 곳체다슬 기 배합사료 개발에 필요한 필수 영양소 요구량 자료를 축적 하기 위하여 적정 단백질 및 에너지 함량, 필수지방산 및 탄수 화물 종류에 따른 이용성에 관한 연구들이 수행되어져 왔다 (Lee et al., 2002; Lim et al., 2003; Lee and Lim, 2005).

소맥분은 양식용 배합사료의 탄수화물원으로써 가장 널리 사용되고 있는 원료로 사료 제조시 성형을 도와주는 점결제로 작용하여 미세한 먼지 등의 부스러기를 잡아줄 뿐 아니라 사료가 수중에 공급되었을 때는 풀림을 방지하여 사료의 수중 유실을 감소시키는 역할을 한다. 또한 탄수화물은 에너지로서 는 가장 값싼 사료원료이기 때문에 대상종의 탄수화물 이용성 을 조사하면 경제적인 배합사료 설계에 도움을 줄 수 있다. 그러나 곳체다슬기 사료 중에 적정 탄수화물 함량에 관한 
연구는 미비한 실정이다. 그래서 본 연구에서는 소맥분 함량 을 달리한 배합사료가 곳체다슬기의 성장 및 체조성에 미치는 영향을 조사하여 사료 중에 적정 소맥분 첨가량을 구명하고자 하였다.

\section{재료 및 방법}

실험사료

실험사료는 단백질원으로 대두박과 콘글루텐밀을 사용하 였으며, 곳체다슬기 사료의 소맥분 이용성을 조사하기 소맥분 을 $35,40,45,50,55$ 및 $60 \%$ 첨가한 6 종류의 실험사료를 설계하였다 (Table 1). 지질원으로는 오징어간유와 대두유를 사용하였으며, 비타민 및 미네랄 혼합물을 각각 동일하게 첨 가하였다. 이와 같이 설계된 원료들을 분말형태로 잘 혼합하 고, 물을 첨가하여 수분을 $40 \%$ 전후가 되도록 하여 moist pellet 제조기로 실험사료를 압출 성형하였다. 성형된 사료는 실온에서 24 시간 건조한 후 $-25^{\circ} \mathrm{C}$ 에 보관하면서 사료 공급시 마다 사용하였다.

Table 1. Ingredients and nutrients contents of the experimental diets

\begin{tabular}{lrrrrrr}
\hline & \multicolumn{1}{l}{ Diets } & & & & \\
\cline { 2 - 7 } & WF35 & WF40 & WF45 & WF50 & WF55 & WF60 \\
\hline Ingredients (\%) & & & & & & \\
Soybean meal & 55 & 50 & 40 & 30 & 20 & 10 \\
Corn gluten meal & & & 5 & 10 & 15 & 20 \\
Wheat flour & 35 & 40 & 45 & 50 & 55 & 60 \\
Squid liver oil & 2 & 2 & 2 & 2 & 2 & 2 \\
Soybean oil & 3 & 3 & 3 & 3 & 3 & 3 \\
Vitamin premix1 & 2 & 2 & 2 & 2 & 2 & 2 \\
Mineral premix2 & 3 & 3 & 3 & 3 & 3 & 3 \\
Nutrient contents (dry & matter basis) & & & & \\
Crude protein (\%) & 34.7 & 33.7 & 33.4 & 34.3 & 34.2 & 33.2 \\
Crude lipid (\%) & 7.2 & 7.3 & 7.6 & 8.4 & 8.0 & 8.2 \\
Ash (\%) & 6.4 & 6.1 & 5.4 & 5.2 & 4.7 & 4.2 \\
Crude fiber (\%) & 4.3 & 4.3 & 3.6 & 3.2 & 2.9 & 2.2 \\
Gross energy (cal/g) & 4767 & 4729 & 4782 & 4872 & 4870 & 4910 \\
\hline
\end{tabular}

1 Vitamin premix contained the following amount which were diluted in cellulose $(\mathrm{g} / \mathrm{kg}$ premix): L-ascorbic acid, 121.2; DL-a-tocopheryl acetate, 18.8; thiamin hydrochloride, 2.7; riboflavin, 9.1; pyridoxine hydrochloride, 1.8; niacin, 36.4; Ca-D-pantothenate, 12.7; myo-inositol, 181.8; Dbiotin, 0.27; folic acid, 0.68; p-aminobenzoic acid, 18.2; menadione, 1.8; retinyl acetate, 0.73; cholecalciferol, 0.003; cyanocobalamin, 0.003 .

2 Mineral premix contained the following ingredients $(\mathrm{g} / \mathrm{kg}$ premix): $\mathrm{MgSO}_{4} \cdot 7 \mathrm{H}_{2} \mathrm{O}, 80.0 ; \mathrm{NaH}_{2} \mathrm{PO}_{4} \cdot 2 \mathrm{H}_{2} \mathrm{O}, 370.0 ; \mathrm{KCl}$, 130.0; Ferric citrate, $40.0 ; \mathrm{ZnSO}_{4} \cdot 7 \mathrm{H}_{2} \mathrm{O}, 20.0$; Ca-lactate, $356.5 ; \mathrm{CuCl}, 0.2 ; \mathrm{AlCl}_{3} \cdot 6 \mathrm{H}_{2} \mathrm{O}, 0.15 ; \mathrm{KI}, 0.15 ; \mathrm{Na}_{2} \mathrm{Se}_{2} \mathrm{O}_{3}$, $0.01 ; \mathrm{MnSO}_{4} \cdot \mathrm{H}_{2} \mathrm{O}, 2.0 ; \mathrm{CoCl}_{2} \cdot 6 \mathrm{H}_{2} \mathrm{O}, 1.0$.

\section{사육관리}

사육실험은 국립수산과학원 중앙내수면연구소에서 종묘 생산되어 사육된 곳체다슬기 중에서 최초 평균체중 $0.61 \pm 0.1$ $\mathrm{g}$ (평균 \pm 표준편차)의 다슬기를 각 사료마다 3 반복으로 18 개의 수조 $(15 \mathrm{~L})$ 에 70 마리씩 수용하여 8주간 실시하였다. 사료는 1일 1회 (10:00) 만복 공급하였으며, 매일 사료공급 전에 먹고 남은 잔량을 제거하였다. 사육수로는 지하수를 각 수조의 환 수율이 1 일 20 회전 정도가 되도록 조절하여 주수하였다. 사육 기간 동안의 평균 수온은 $18 \pm 2.0{ }^{\circ} \mathrm{C}$ 였다.

어체측정 및 성분분석

사육실험 종료시에 측정 전일 절식시킨 후, 각 실험수조에 수용된 곳체다슬기 전체 무게를 측정하였으며, 모든 실험다슬 기는 성분분석용으로 샘플 채취하여 냉동보관 $\left(-75^{\circ} \mathrm{C}\right)$ 하였 다. 실험사료와 다슬기의 수분은 $135^{\circ} \mathrm{C}$ 에서 2시간 건조하여 측정하였으며, 조단백질 $(\mathrm{N} \times 6.25)$ 은 Auto Kjeldahl System (Gerhardt VAP50OT/TT125, Germany)을 사용하여 분석하였 다. 조지방은 조지방추출기 (Velp SER148, Italy)를 사용하여 ether로 추출한 후 측정하였으며, 조회분은 회화로를 사용하여 $550^{\circ} \mathrm{C}$ 에서 4시간 동안 태운 후 정량하였다. 에너지함량은 열량 분석기 (Parr-6200, Moline, IL, USA)를 사용하여 분석하였다.

\section{통계처리}

결과의 통계처리는 SPSS 프로그램을 사용하여 One-way ANOVA-test를 실시하여, Duncan's multiple range test (Duncan, 1955)로 평균간의 유의성을 검정하였다.

\section{결과 및 고찰}

소맥분 함량을 달리한 사료로 곳체다슬기를 8 주간 사육한 결과 생존율은 모든 실험구에서 $85-92 \%$ 였으며, 실험구간에 통계적인 차이는 없었다 $(P<0.05)$ (Table 2). 증체량은 소맥분 $35 \%$ 및 $40 \%$ 실험구가 가장 높았으며, 소맥분 함량 $45 \%$ 이상 의 실험구에서는 유의하게 감소하는 결과를 보였다 $(P<0.05)$.

탄수화물은 사료의 성형을 도와주는 역할을 할 뿐 아니라 체내의 중요한 에너지원으로 사용되기 때문에 사료 단백질을 절약할 수 있으며, 탄수화물원은 단백질원 및 지질원에 비하 여 가격이 낮기 때문에 대상종에 대한 이용성이 연구되면 사료단가를 절감 할 수 있는 영양소이다. 어류의 탄수화물 이용성은 어종에 따라서 차이를 나타내는데 (NRC, 1993), 이 러한 탄수화물 이용률의 차이는 어종별 소화기관의 차이, 사 료내 탄수화물원의 종류 및 함량과도 관련이 있는 것으로 알려져 있다 (Bergot, 1979; Hutchins et al., 1998). 일반적으로 온수성 초식 및 잡식성 담수어류는 연어류와 같은 냉수성 어류 및 해산어류에 비하여 탄수화물 이용률이 높은 것으로 알려져 있다 (Wilson, 1994). 잉어 (Cyprinus carpio), 찬넬메기 (Ictalurus punctatus) 및 틸라피아 (Tilapia zilli)는 사료의 비단 백질 에너지원으로써 탄수화물을 지질 보다 더 효율적으로 사용하는 것으로 보고되었으며 (Ogino et al., 1976; Garling and Wilson, 1977; Anderson et al., 1984), 사료 중의 적정 탄수화 
물 함량은 잉어는 30-45\% (Ufodike and Matty, 1983; Satoh, 1991), 틸라피아는 37-40\% (El-Sayed and Garling, 1988; Lequet, 1991) 및 grass carp (Ctenopharyngodon idella) (Lin, $1991)$ 는 37-56\%로 보고되었다. 곳체다슬기 치패도 사료 내 지질함량 증가에 따른 성장개선 효과는 나타나지 않았으며 (Lee and Lim 2005), Lim et al. (2003)은 탄수화물원으로 glucose, maltose, a-cellulose, 전분 및 소맥분을 사용한 사료로 곳체다슬기 치패를 사육한 결과, 모든 실험구의 생존율 및 성장률에 차이가 없는 것으로 보고하였다.

Table 2. Survival and weight gain of snail fed diets containing the different wheat flour levels for 8 weeks

\begin{tabular}{|c|c|c|c|c|c|c|}
\hline & \multicolumn{6}{|c|}{ Diets } \\
\hline & WF35 & WF40 & WF45 & WF50 & WF55 & WF60 \\
\hline Survival (\%) & $92 \pm 1.3^{\text {ns }}$ & $85 \pm 3.1$ & $89 \pm 1.1$ & $91 \pm 0.8$ & $91 \pm 2.2$ & $85 \pm 3.3$ \\
\hline $\begin{array}{l}\text { Weight gain } \\
\text { (mg/snail) }\end{array}$ & $173 \pm 7.8^{\mathrm{a}}$ & $194 \pm 4.8^{\mathrm{a}}$ & $129 \pm 7.8^{b}$ & $94 \pm 1.3^{\mathrm{c}}$ & $65 \pm 10.2^{\text {cd }}$ & $53 \pm 17.4^{d}$ \\
\hline
\end{tabular}

Values (mean \pm SE of three replications) in each row with a different superscript are significantly different $(P<0.05)$.

ns Not significant $(P>0.05)$.

Table 3. Proximate composition (\%) of whole body in snail fed diets containing the different wheat flour levels for 8 weeks

\begin{tabular}{ccccccc}
\hline & \multicolumn{6}{c}{ Diets } \\
\cline { 2 - 7 } & WF35 & WF40 & WF45 & WF50 & WF55 & WF60 \\
\hline Moisture & $38.4 \pm 0.6^{\text {ns }}$ & $38.0 \pm 0.7$ & $35.9 \pm 0.3$ & $37.1 \pm 0.4$ & $38.1 \pm 1.4$ & $36.1 \pm 1.5$ \\
Crude protein & $5.7 \pm 0.3^{\mathrm{a}}$ & $5.6 \pm 0.3^{\mathrm{a}}$ & $4.6 \pm 0.1^{\mathrm{ab}}$ & $4.8 \pm 0.1^{\mathrm{ab}}$ & $5.0 \pm 0.6^{\mathrm{ab}}$ & $4.3 \pm 0.3^{\mathrm{b}}$ \\
Crude lipid & $0.3 \pm 0.0^{\text {ns }}$ & $0.3 \pm 0.0$ & $0.4 \pm 0.1$ & $0.4 \pm 0.1$ & $0.2 \pm 0.0$ & $0.2 \pm 0.0$ \\
Ash & $48.8 \pm 1.3^{\mathrm{a}}$ & $42.1 \pm 3.7^{\mathrm{ab}}$ & $51.2 \pm 0.6^{\mathrm{a}}$ & $49.4 \pm 0.4^{\mathrm{a}}$ & $39.3 \pm 5.7^{\mathrm{b}}$ & $33.9 \pm 0.9^{\mathrm{b}}$ \\
\hline
\end{tabular}

Values (mean \pm SE of three replications) in each row with a different superscript are significantly different $(P<0.05)$. ${ }^{\text {ns }}$ Not significant $(P>0.05)$.

사료 중에 적정 함량의 탄수화물 첨가는 단백질이 에너지원 으로 사용되는 것을 감소시켜 단백질 효율을 향상시킬 수 있으며 (Wilson, 1994), 어류 및 새우류의 성장을 향상시키는 것으로 알려져 있다 (Anderson et al., 1984; Alava and Pascual, 1987; Hemre et al., 1995; Hung et al., 2003). 사료의 탄수화물원 으로 소맥분 함량을 달리한 본 연구에서 사료 중에 소맥분 함량 $45 \%$ 이상에서는 곳체다슬기의 증체량이 감소하는 결과 를 나타내어, 곳체다슬기의 성장을 위해서는 배합사료에 소맥 분을 35-40\% 첨가하는 것이 적합할 것으로 판단된다. Lee et al. (1998)은 참전복 (Haliotis discus hannai)을 대상으로 탄수 화물의 이용성을 조사한 결과, 성장 감소 없이 사료 중에 탄수 화물을 $50 \%$ 까지 사용이 가능하며, 본 연구 결과와 유사하게 참전복의 경우에도 탄수화물 이용성이 상당히 높은 것으로 보고하였다. 어류의 경우, 특히 육식성 어류는 사료 중에 탄수 화물을 과다하게 첨가하면 성장 및 사료이용율이 감소하는 것으로 알려져 있다 (Wilson 1994). Lee and Kim (2009)은 탄수화물 24-30\% 사료를 먹은 조피볼락 Sebastes schlegeli 치 어는 탄수화물 6-18\% 사료 섭취 실험구에 비하여 성장 및
사료효율이 감소하였다고 보고하였으며, subshine bass (Morone chrysops $\times$ M. saxatilis) 치어도 $40 \%$ 탄수화물 첨가구 는 $20 \%$ 탄수화물 첨가구에 비하여 성장, 사료효율 및 단백질 효율이 감소하는 결과를 보였다 (Hutchins et al., 1998). 또한 적정량 이상의 탄수화물이 첨가된 사료를 섭취한 silver barb (Puntius gonionotus)는 사료 중의 단백질 및 에너지 소화율이 감소하였으며, 단백질 및 탄수화물 분해효소의 활력도 감소하 는 것으로 보고되었다 (Mohanta et al., 2009).

사육실험 종료 후, 곳체다슬기의 일반성분 분석 결과를 Table 3에 나타내었다. 다슬기의 수분 및 조회분 함량은 모든 실험구간에 유의한 차이가 없었으나, 조단백질 및 조지질 함 량은 실험사료에 유의한 영향을 받았다 $(P<0.05)$. 조단백질 함량은 소맥분 $35 \%$ 및 $40 \%$ 실험구가 소맥분 $60 \%$ 실험구에 비하여 유의하게 높았으나 $(P<0.05)$, 소맥분 $45-55 \%$ 실험구와 는 유의한 차이가 없었다. 조회분 함량은 소맥분 $35 \%, 45 \%$ 및 $50 \%$ 실험구가 소맥분 $55 \%$ 및 $60 \%$ 실험구에 비하여 유의하 게 높았으나 $(P<0.05)$, 소맥분 $45 \%$ 실험구와는 유의한 차이가 없었다. 어류의 경우 사료 중에 탄수화물 증가는 어체내 지질 축적량을 증가시키는 결과가 silver barb, eel (Anguilla anguilla) 및 rohu (Labeo rohita)에서 보고되었다 (Degani and Viola, 1987; Erfanullah and Jafri, 1995; Mohanta et al., 2009). 이는 사료로 섭취된 과잉의 탄수화물이 지질로 축적되었기 때문이 며, 고함량의 탄수화물 사료를 섭취한 찬넬메기의 경우 지질 합성 활력이 증가하는 것으로 보고되었다 (Likimani and Wilson, 1982). 그러나 본 연구에서는 모든 실험구의 다슬기 지질함량은 $0.2-0.4 \%$ 로 전반적으로 낮았으며, 사료중의 탄수 화물 함량에 따른 차이를 보이지 않았다.

이상의 결과로 볼 때, 곳체다슬기의 성장을 위해서는 배합 사료에 소맥분을 $35-40 \%$ 첨가하는 것이 적합할 것으로 판단 되며, 이러한 결과는 경제적이고 영양적으로 균형있는 다슬기 용 배합사료를 설계하는 데 기초자료가 될 것으로 기대된다.

$$
\text { 사 사 }
$$

본 연구는 국립수산과학원 (내수면 양식기술 개발, RP-2010-AQ-099)의 지원에 의해 수행되었습니다.

\section{참고문헌}

Alava VR and Pascual FP. 1987. Carbohydrate requirements of Penaeus monodon (fabricius) juveniles. Aquaculture 61, 211-217.

Anderson J, Jackson AJ and Capper BS. 1984. Effects of dietary carbohydrate and fibre on the tilapia, Oreochromis niloticus (Lin.). Aquaculture 37, 303314.

Bergot F. 1979 Carbohydrate in rainbow trout diets: Effects of the level and source of carbohydrate and the number of meals on growth and body composition. Aquaculture 18, 157-167. 
Davis GM. 1969. A taxonomic study of some species of Semisulcospira in Japan. Malacologia 7, 211-294.

Degani G and Viola S. 1987. The protein sparing effect of carbohydrate in the diet of eels (Anguilla anguilla). Aquaculture 64, 283-291.

Duncan DB. 1955. Multiple-range and multiple F tests. Biometrics 11, 1-42.

El-Sayed AM and Garling DL. 1988. Carbohydrate-tolipid ratios in diets for Tilapia zilli fingerlings. Aquaculture 73, 157-163.

Erfanullah and Jafri AK. 1995. Effects of dietary carbohydrate level on the growth and conversion efficiency of the Indian major carp fingerling, Labeo rohita (Ham): a preliminary study. Asian Fisheries Science 6, 249-253.

Garling DL and Wilson RP. 1977. Effects of dietary carbohydrate-to-lipid ratios on growth and body composition of fingerling channel catfish. Progressive Fish-Culturist 39, 43-47.

Hemre GI, Sandnes K, Lie O, Torrissen O and Waagbo R. 1995. Carbohydrate nutrition in Atlantic salmmon, Salmo salar L.: growth and feed utilization. Aquac Res 26, 149-154.

Hung LT, Lazard J. Mariojouls C and Moreau Y. 2003. Coparison of starch utilization in fingerlings of two Asian catfishes from the Mekong River (Pangasius bocourti Sauvage, 1880, Pangasius hypophthalmus Sauvage, 1878. Aquac Nutr 9, 215-222.

Hutchins CG, Rawles SD and Gatlin DM. 1998. Effects of dietary carbohydrate kind and level on growth, body composition and glycemic response of juvenile subshine bass (Morone chrysops 우 $\times$ M. saxatilis $\delta)$. Aquaculture 161, 187-199.

Hwang GD, Kim LO, Park JH, Bang IC, Kim KD, Jang HS and Lee SM. 2003. Utilization of soybean meal and wheat flour in different types of diets for juvenile snail (Semisulcospira gottschei). J Kor Fish Soc 36, 454-457.

Likimani TA and Wilson RP. 1982. Effect of diet on lipogenic enzyme activities in channel catfish hepatic and adipose tissue. J Nutrition 112, 112-117.

Lee SM, Yun SJ, Min KS and Yoo SK. 1998. Evaluation of dietary carbohydrate sources for juvenile abalone (Haliotis discus hannai). J Aquacult 11, 133-140.

Lee SM and Kim KD. 2009. Effects of dietary carbohydrate to lipid ratios on growth and body composition of juvenile and grower rockfish, Sebastes schlegeli. Aquac Res 40, 1830-1837.

Lee SM and Lim TJ. 2005. Effects of dietary protein and energy levels on growth and lipid composition of juvenile snail (Semisulcospira gottschei). J Shellfish Res 24, 99-102.

Lee SM, Kim KD, Lim TJ and Bang IC. 2002. Effects of dietary lipid sources on growth and body composition of snail (Semisulcospira gottschei). J Fish Sci Tech 5, 165-171.

Lequet P. 1991. Tilapia, Oreochromis spp. In: Handbook of Nutrient Requirement of Finfish (ed. by Wilson RP), CRC Press, Boca Raton, FL, U.S.A., 169-179.

Lim TJ, Kim KD, Kim SH, Lee SM and Bang IC. 2003. Effects of different dietary carbohydrate sources on growth and body composition of juvenile snail (Semisulcospira gottschei). J Aquacult 16, 187-189.

Lin D. 1991. Grass carp, Ctenopharyngodon idella. In: Handbook of Nutrient Requirement of Finfish (ed. by Wilson RP), CRC Press, Boca Raton, FL, U.S.A., 89-96.

Mohanta KN, Mohanty SN, Jena J, Sahu NP and Patro B. 2009. Carbohydrate level in the diet of silver barb, Puntius gonionotus (Bleeker) fingerlings: effect on growth, nutrient utilization and whole body composition. Aquac Res 40, 927-937.

NRC (National Research Council). 1993. Nutrient requirements of Fish, National Acadamy Press, Washington, DD, U.S.A., 114.

Ogino C, Chiu JY and Takeuchi T. 1976. Protein nutrition in fish-VI. Effect of dietary energy sources on the utilization of protein by rainbow trout and Carp. Bull Jpn Soc Sci Fish 42, 213-218.

Satoh S. 1991. Common carp Cyprinus carpio. In: Handbook of Nutrient Requirement of Finfish (ed. by Wilson RP), pp. 55-67. CRC Press, London, U.K.

Ufodike EBC and Matty AJ. 1983. Growth response and nutrient digestibility in mirror carp (Cyprinus carpio) fed different levels of cassava and rice. Aquaculture 31, 41-50.

Wilson RP. 1994. Utilization of dietary carbohydrate by fish. Aquaculture 124, 67-80.

2010년 10월 6일 접수

2010년 11월 25일 수정

2010년 12월 3일 수리 